\section{Self-confidence and executive presence an image consulting process}

Lynne Marks*

\begin{abstract}
The purpose and goal of this abstract is to demonstrate that image consulting services help boost clients' self-confidence. Our clients at London Image Institute are entrepreneurs and executives. Over years of honing our Executive Presence programs and courses for entrepreneurs we noticed that these techniques, skills and coaching programs are particularly effective in enhancing self-confidence, even in high level business people and entrepreneurs. We will share the agendas of the programs with the readers as well as some of the methods by which we shift mindsets and bring about sustained life-changing skill sets. At the end of each section there will be a short synopsis of the image consulting practices our clients reported were most effective in confidence-building.
\end{abstract}

Keywords: Executive - Presence - Self-Confidence - Self-Trust - Self-worth - Self-Esteem - Self- Management - Image Consulting.

[Abstracts in spanish and portuguese at pages 43-44]

${ }^{*}$ Certified Image Master Lynne Marks is President of London Image Institute. Lynne headed the image and fashion modeling departments at the London College of Fashion, becoming experienced in image, styling, fashion trends, fashion show production, body language, makeup and modeling. She was also exposed to theories of color, design, tailoring and garment construction. Lynne is co-author of "The Perfect Fit: How to Start an Image Consulting Business", an industry best seller and author of "Skinny Bits: Wisdom for a Flourishing Image Business." Lynne is twice Past International President of the Association of Image Consultants International, (AICI).

\title{
Our definition of self-confidence
}

Self-confidence is defined for this abstract and used interchangeably with other terms such as self-trust, self-reliance, self-worth and self-esteem. Of the self-esteem indicators measured in studies, three were prominent: appearance, performance and close relationships. In my experience, the indicators of self-confidence in men are performance based: facing the next hurdle, overcoming challenges and improving skills. Alternatively, selfconfidence in women is based in the quality and closeness of their relationships. In both genders appearance is also highly correlated with self-confidence. 
Just as in the case of technical skills, mastery and proficiency of the soft skills to an outcome or result frequently brings about a trust in one's performance, improves our communication with friends and colleagues and enhances our appearance. All result in a boost of self-confidence. I have found that mastery of these skills leads to not only heartfelt client testimonials saying that our work is life-changing but also to tangible results. These include promotions, improved work performance, successful fundraising ventures, interview packages for positions that surpass the clients' dreams.

\section{The difference between styling and image consulting}

It is important to note that image and styling are different, although many people think image consultants are stylists and fashionistas. Actually there is quite a difference. Strictly speaking, stylists work on dressing their personal clients for events; some can also style outfits for catalogues, magazine photo shoots, videos, head shots, traditional and online publications and social media. They can also work on the styling of clothing and organization of fashion shows. Stylists tend to be fashion and clothing oriented.

On the other hand, image consulting services encompass much more than styling. Although many of our services include some styling, we also work in-depth on the appearance, behavior, verbal and non-verbal communication skills of our clients.

We understand communication skills such as business communication, leading meetings, TV appearances, interview skills and public speaking. Fast-trackers, celebrities, sportspeople, entrepreneurs, interviewees and everyone in line for promotion all need our executive presence services. Our roles are many and varied and it behooves us to learn myriad skills ourselves to deliver a holistic service to the client. Appearance is simply not enough. If we don't have the skills personally, we can partner with other expert associates to help us work on every aspect of a client's executive presence. These specialists might include voice trainers, media specialists, speakers, actors, makeup artists, writing experts, CV writers, professional organizers and business coaches.

\section{How image consulting services impact self confidence}

As trainers, motivational speakers, entrepreneurs, consultants or coaches, image consultants are well positioned to develop long term programs with sustainable practices and life-changing results to help clients such as corporate managers, entrepreneurs, spokespeople, politicians, celebrities and sports people. The purpose of our work is people and goal oriented.

Fortunately, to be effective at image consulting we do not need to be psychologists, therapists or have higher degrees in the inner workings of the mind. Rather than regarding self-confidence as some intangible quality that some people have and others will never have, another perspective is available. Known in the corporate world as soft skills, our services concentrate on learned and practiced skills through appearance; behavior; communication; presentation; personal branding, self-management and goal fulfillment, which 
contribute to the personal and professional development of our clients. These skills can have key performance measures or outcomes, lending credibility to our clients' results. They involve discipline, self-discipline and personal responsibility, which, far from being detrimental, actually act as important organizing principles in our clients' daily lives. Furthermore, there is a "feel-good" factor. Feeling good about our accomplishments and having faith in ourselves to reach our goals further enhances our confidence and feeling of self-worth.

\section{The guiding distinctions of a successful executive presence program}

Our work is successful if it includes some transformational practices, which result in improved performance, more challenging projects and an altered mindset. This process requires three critical distinctions. Our services and trainings need to come from the heart, the head and the soul. Take Apple as an example which embodies all three elements. Over the years, they transformed clunky machines into beautiful artifacts which can also make the Apple owner's work aesthetically pleasing. We loved the ease, the colors, the fonts and the style. We even felt proud to own an Apple because we felt that their values of innovation and beauty: sleek, modern and stylish, were now ours.

- Heart is the emotional component. People must identify with our message and be moved or touched and in some way influenced. Our clients become loyal fans. Oprah Winfrey's stand is to help people better understand themselves; to follow a life of substance and to help people be their best. It's a universally appealing message and as a result she has a world-wide following.

- Head is the logical, educational and informational component. Our clients are armed with information, skills and an in-depth knowledge of how to solve their pressing problems. Their existing performance has been enhanced and the changes are sustainable.

- Soul is the inspirational, transformational component. Our clients tell us that they have a higher regard for themselves after our services. They tell us they look back and feel a difference in their attitude to life and now have control over their particular knotty issues. Our programs and training instill certain values so that the client can incorporate them into that which is important to them too.

\section{Vision stand for something, live it and contribute it}

Finding a vision requires a process of discovery and self-awareness and in this exercise the clients discovers their life's purpose. This is defined as a stand for the world or a vision for the health of the planet to which they are willing to devote time, money and resources, either as part of their work or in their other pursuits. However, a personal or self-interest is essential, and one's vision for the world must include the client's personal passions. We start by asking the client what he or she wants personally. The list can include money, material items or non-material items. The list is very difficult for some people because 
upbringing, culture and parental influence discourage wanting anything on the grounds that we mustn't be selfish. Nevertheless, we encourage them to write at least a page of items. Once their limitations and inhibitions are set free, we ask them what they want for the world. The pens start writing rapidly and very soon they have expressed their deepest longings for a world that works. Another way of accessing the vision is to draw a vision board but in this case we find that words are more powerful. We have a process to distill these vision descriptions down to three or four hard salient words that can be crafted into an inspiring sentence or phrase.

\section{Synopsis}

- Articulating the world they dream of; a world they would be proud to leave to their great grandchildren.

- Owning the vision.

- Willing to work towards achieving it.

- It's a cathartic and enlightening experience for many clients to know that they are driven by a vision greater than by their own circumstances.

- Realizing that they can make a difference at work, home and anywhere else they can.

\section{Messages}

In image consulting, a message is defined as a verbal, visual or non-verbal communication, intentionally or inadvertently delivered or projected by the individual. However, there is always another element to messages. That is, the one that is received or perceived by others. In image consulting our job is to ensure that the visual, verbal and non-verbal messages projected are clearly expressed and received by the listener or observer in the same vein. In other words, "Are you hearing or observing what I intend to say, about myself, and what is important to me?" When we ask clients what they want to project to the world they give traits such as confident, credible, friendly, reliable, trustworthy, current thinker, team player, fitting in, standing out. After an examination of these words the client realizes that although he has never given much thought to what messages he projects he has just expressed his values, skills or goals. We ask clients to think of people they admire who leave them inspired or moved. They frequently notice that their icons' work and personal practices, body language and appearance are consistent with their message. They share and give away their values; they withstand and overcome adverse situations with honesty, and they always seem to be current and relevant. They are comfortable in their own skin.

- Clients look, act and speak in a manner consistent with their intentions and what is important to them.

- Their visual, verbal and non-verbal messages are consistent with their skills, talents, vision, values and goals.

- Representing themselves powerfully they grow and develop in skills and stature. 


\section{Influence}

Influence has two facets: the example set personally, "on the job", and secondly the verbal, non-verbal and visual expression of values and purpose that are projected.

These are some of the non-verbal practices to influence others which the client can put into practice in his daily life.

- Friendship and respect. Be a trusted advisor and you automatically have more influence than a being mere acquaintance. A valuable bond emerges in a relationship when people feel supported. Influential people always seem to have a faithful fan club of committed followers.

- Humility. Executives must perfect their own skills and inspire and motivate people with their own example, actions and practices.

- Generosity. Generosity in kind such as gifts and reciprocity are delightful but also generosity of spirit such as time spent, kindnesses and any authentic gestures of outreach have a powerful ability to bond people emotionally. Both can illicit our intuitive sense of indebtedness, fairness and commitment.

\section{Finding the values of the client}

Using our three-pronged approach, heart, head and soul we have a process to help a client determine what is important to him. Through a series of exercises we drill the executive client through a series of questions to get to his values and then distill those words down to three or four core values.

- What do you stand for?

- What is important to you?

- How do you contribute yourself?

- Where and with whom do you share yourself?

- How do you grow and develop others?

A simple exercise to find out what is important to our client is to ask him:

"Describe a situation of which you were most proud." After a surprisingly short time the client will tell you a story in all its glorious detail of the moment he felt he was operating at his peak performance. His "best self" emerged triumphant. The consultant or coach can ask the client all the things that were important to him, (his values) in that situation. He can also find where those values often show up elsewhere in his life and spike conversations, promote action and bring joy to life. Values are incrementally enhanced if we share them or give them away to others. For example, if one of our values is to grow and develop people there is nothing more rewarding than seeing our teams, coworkers, class students and children grow before our eyes. 


\section{Discovering the voice}

We have established that critical components in finding the voice are the ability to convey vision, passion, guiding principles and values. The articulation of those messages might be heard and demonstrated in many areas of life such as the workplace or business venture. However, a client's voice could become more distinct in any of the other roles he plays in life: charitable, professional or civic associations, with associates and friends, as a parent, club manager or board member and many others. Naturally younger clients will also have a voice but that too will evolve, develop and flourish over time. It's important to teach our clients, young to experienced, the process and critical elements to create executive presence, starting with their natural messages, the combination of which is known as the voice. The package created is reflected in the voice, words, appearance and body language to radiate a charisma that is infectious and inspiring. Furthermore, contributing values to help people grow is a major step to elevating the message to a new public level.

\section{Synopsis}

- The voice is a personal stand, a body of experience and overarching messages which are created, honed and developed over time.

- It represents a profound appreciation of self, not as a personality but as a spokesperson for something greater than the self.

- It contributes to the personal brand.

\section{The visual impact}

The appearance side of our work includes color, figure and style analysis, organizing and purging our clients' wardrobes, shopping for their day to day clothing for work, vacations and social events, dressing them for presentations, interviews and important events and generally making them look good all the time! We create consistency between three elements: the client's values and goals, her lifestyle and her physical characteristics.

In my experience, appearance for the executive level is the most compelling of the confidence builders, for several reasons. The visual brain in humans is larger than any other part of the brain, consequently humans put great stock into what they see.

\section{Exercises we do}

We ask our clients and our students: "What would you like to look like? Write down a few ideas." A close examination of the list of words might surprise you. At first I thought my clients would refer to their wardrobes and talk about the type of clothing they liked such as tailored jackets, a little black dress, floral fabrics and other visual references. But they didn't. Instead they said things like: approachable, a leader, confident, more stylish, professional, ability to be promoted. After probing a bit in coaching mode I was able to get to 
the bottom of what they meant by each word. I asked them if they looked approachable now and if the answer was no, then it was a goal for them. If it was a word that translated into a learned activity is was a skill; if they say that they had always been friendly and approachable, it was a natural talent. Many of the words were concepts, umbrella terms that meant several things and different things to different people. I needed to get to the basic meaning for them personally. For example, "professional" turned out to mean reliable for one, credible for another and trustworthy for a third. Often they would explain a listed word passionately and I was able to extrapolate other words to add to the list. Words such as leader for example led to other meanings such as strength, charisma, contribution and leadership the noun, all representing the way they not only wanted to look but also the way they wanted to live their lives.

The exercise is fascinating and more profound than the client expects. Our observational research over twenty-five years discovered that human beings want their appearance to represent their skills, talents, experience, vision, values and goals: those attributes which are important to them in life. Our next job was to translate those important words into clothing choices. Approachable for example can be demonstrated by lighter or more muted colors, softer fabrics, curvier lines and more textured finishes. Credibility can be shown by tailored styles, straighter lines, smooth fabrics and darker shades with high contrast. This important step in the process ensured that the client and consultant are on the same page and could move forward. Once armed with all this information a schedule of the basic appearance services for the client can be created such as body and color analysis, style stories, so that her preferences, figure type, bone structure and color harmonies and facial shapes and scales matched her desired final image. Then follows the wardrobe and shopping services.

\section{Client examples}

I took a client shopping and chose some clothing styles out of her comfort zone. As she looked at herself in her new outfit, right there in the changing room her posture straightened up and she started fixing her hairstyle because suddenly that detail didn't match the new look. Then she promptly burst into tears (of joy), saying that her husband wouldn't know her. The outfit not only changed her shape, coloring and style but also altered her mindset, attitude and the message she projected to the world. She couldn't believe that it's the same person. We also changed the hairstyle and the makeup and her husband was very pleased. These changes make a huge difference. Since hair is growing out of our heads; it's an integral part of us, representing a communication of it's own. Whether we like it or not, that "language" has now altered, sometimes for good. The makeup enhanced her beauty, made her look more vivid and brought out her best features. Finally, there is a well-known phenomenon called The Halo Effect that comes into play when a favorable reaction to an attractive person spills over to positive thoughts of the client in other, unrelated areas. For example, anecdotal evidence suggests that a coordinated outfit is interpreted by others as good organization; impeccable grooming translates into attention to detail, and appropriateness is viewed as walking the talk and professionalism. When our clients go out or to 
work with an improved image the message they are projecting also changes. The process is always similar: others see them; their first impression changes and their view of our client also shifts. They even treat the client differently. One of my clients seeking a top level job in a national hospital organization changed her wardrobe, hair and makeup drastically. Her close colleagues teased her and asked her if she was having an affair! Another lady said that people now ask her opinion in meetings and she is now part of the team. The halo effect also comes into play.

\section{Synopsis}

Below are some common results we have seen in our appearance clients over the years.

- New self-image. When they try on new clothing, clients see a totally different image in the mirror and get a new impression of themselves.

- Hairstyle and other details. I have found that of all the details changed, the hairstyle for women contributes the most profound shift in their perspective of themselves.

- The attitude of others towards them. The feel-good factor. Clients are affected emotionally by the reaction of others to their improved appearance. If those reactions are favorable the client's self-image is enhanced and her self-confidence is frequently boosted.

\section{The effect of color on self-confidence}

The colors we are drawn to are hugely influenced by our habitat, environment, upbringing, culture, age, background and experience. Despite the body of work called Color Psychology our personal preferences and interpretations override many of the known definitions. They are largely inherited and handed down from our past experience. However, that does by no means negate the fact that color plays an extraordinarily emotional role in the way we perceive practically anything: clothing, cars, logos, interiors, fruit, flowers, vegetables, furniture, spices and food. We know from studies that colors affect perception of a brand or a product.

\section{Personal color analysis and the colors we wear}

When buying clothing we buy colors with little or no thought of three important elements

- The effect the color is having on our brain

- The effect color has on our personal appearance

- The messages that color is sending.

As a rule, we simply choose what our personal preferences dictate, given by our childhood or young adulthood history with that color. This is no different from the way we choose clothing: we buy the colors we like--- hardly the best strategy if we want to project a consistent message of confidence and credibility. Since color is such a powerful communicator 
the right colors can have an amazing effect on how the client looks and feels. The wrong shade can make skin and eyes look dull and lifeless. It can add unflattering shadows around the nose, mouth and under the eyes and jaw line. Any blotchiness, imperfections and rough skin are emphasized. This has the effect of adding artificial age lines, pouches and an uneven jaw line. I have never been told by a client: "Please make me look old and sick!"

\section{Synopsis}

Some of the benefits of wearing colors that harmonize with the client's natural coloring.

- Radiant: Color can enhance the brightness of a person adding luminosity to their eyes, and hair and a flattering luster to their skin.

- Healthy: Correct and flattering colors have the effect of creating an even skin tone. Youthful. The right colors can add color under the face tightening the jaw line, erasing dark shadows under the eyes and lifting the cheekbones to make the face look much fuller and more youthful.

- The feel-good factor. Feeling more attractive, healthy and youthful. A woman especially mourns the disappearance of her youthful look; everyone loves looking energetic and lively. Color has a powerful psychological effect on self-perception and mood.

\section{Self marketing skills}

Many of our clients lack the skills of self-promotion. But as an executive or entrepreneur they are essential. Our clients must answer the question: "Why are you different?" We urge them not to guess! A stellar reputation is not born from our internal assessment, but a close analysis of what our critics, coworkers and fans' experience is of us. To access this information our process often employs the 360 ' Reach survey sent out to 20 of the client's friends, family and colleagues. The surveys are sent back directly to the company who issues the image consultant with a lengthy report. We can go over this useful tool to find out what people value about the client and share the strengths and flaws with him. Another way is to read written testimonials, evaluations and internal assessments to embellish this information.

\section{The personal profile. Demonstration of credibility, experience, specialization}

Writing one's personal profile can be uplifting. Rather than a litany of the positions the client has held over the years which is curriculum vitae, the personal profile is a shorter record of the highlights of the client's career. It becomes an important promotional tool in professional social media sites such as LinkedIn, websites or social media sites for job seekers. It's his showcase to the world. In the following exercise, the client has to write his major positions and the results, outcomes, people he grew and developed and the skills he demonstrated in each position, with examples. In the case of my sales manager client for 
example, we asked for three measures: the time he had been at the job, the increased sales compared to his predecessor and the percentage increase since he began. We asked who of his team under his leadership became star performers? What skills did he teach them and what attributes and skills did he manifest on that job? Initially, he said "team building and communication", but that was too conceptual for us. We drilled down even further and discovered that his true gift was extraordinary customer service. He had developed an innovative service plan for the sales team, constantly making sure that the plan was consistently implemented by the sales team. As a result, they increased sales by $15 \%$ in two years. In addition, two new team leaders trained under him emerged as star performers. His transferrable skills were actually service and relationship building. Constantly honing his skills and keeping abreast of new techniques granted the client credibility. Communicating results with researched and correct facts and knowledge of what worked established my client as some executive others could trust. Furthermore, he discovered that those very same skills honed from his last job, moved with him to his next position of regional manager.

\section{Synopsis}

- Written in the profile format, clients are proud of their experience and accomplishments.

- Realizing that they do in fact make a difference to processes at work.

- Sharing their values.

- Compiling accomplishment and results they have produced in one written piece.

- Honing the capacity to grow and develop people.

- Viewing the personal profile as evidence of their leadership, a values-driven and vision focused life.

\section{Presentation and communication techniques}

The ability to speak in public, addressing a group or an individual is a valuable skill and a builder of self-confidence for executives. In fact, it may be the most important, since at least $90 \%$ of executives fear public presentations. The first hurdle is to overcome nerves, then master the technical skills and finally to speak persuasively to an audience. Our executives must engage people's emotions by speaking from their own heartfelt experience with a laser beam focus into the mindset and experience of their team members or audience. The ability to touch hearts and minds is the capacity to be influential. Defined as "the power to cause a change of character, thought or action in others", influence is one of the most important elements of executive presence, to be believed and to move and inspire the group or audience. Everyone from the top to the bottom of an organization can influence clients, friends, family, work associates and teams. We influence each other frequently, by our manners, appearance, body language, work and personal practices, habits and language, without even knowing it. 


\section{The dimensions of perception}

When we first meet people for the first time we assess them by these two dimensions.

- Warm and Approachable

- Credible and Powerful

As politicians know, speakers who are high on the power scale and lower on the warm-approachable scale appear more threatening than others who rate high on warm-approachable. The audience gears up instantly to ward off threat. They love and gravitate towards warm people because they feel safe with them. However, as much as the warm-approachable dimension is admired, the powerful-credible dimension is also an essential quality and much coveted. We must help our clients demonstrate non-verbally that they can project both dimensions at once, or one or the other when the situation demands.

Luckily we borrow the skills of the stage actor to help us. In our programs we work with the client on content and delivery, timing, flow, vocal impact and body language. This was actually a skill I had learned for many years. As a post graduate student, specializing in kinesthetic and movement based on work done by Rudolph Laban, my research was on Movement and Dance as Therapy. Later I was fortunate enough to be tutored by an experienced acting coach, and I practiced the elements of movement and presentation: use of personal and presentation space, posture, gestures, eye contact and facial expressions. I have been passing on those valuable tools ever since to help my clients become warmapproachable and powerful-credible. When people display a combination of both, they are perceived as confident and charismatic. Not only that, with practice and feedback they feel more self- confident themselves.

\section{Body language}

From 1970's specialists have known the power of body movement in altering the mood of the audience and the speaker. In the case of the speaker, changes in facial expressions, posture, stance, gestures and use of space can change his mood, and are heard in alterations of tone, pitch and volume and a focus of eye contact. Similarly, an audience that is moved becomes very quiet, with no fidgeting and listens intently. No one yet knows for sure why our facial expressions influence emotions but the associations in our mind between how we feel and how we react may be so strong that our expressions simply end up reinforcing our emotions -there may be no evolutionary reason for the connection. Even so, our faces do seem to communicate our states of mind not only to others but also to ourselves. "I smile, so I must be happy," Judith Grob says.

When we train our clients in the two dimensions of perception, body language plays a large role. Warm-approachable body language displays are (among other elements) curved arm movements and flexible gestures, a ready smile that hits the eyes, relaxed and slower movements, a 2-3 second eye contact and listening with steady eye contact. Humor is a really good technique to increase the approachable dimension. On the other hand, cred- 
ibility and power are demonstrated by an erect posture and balanced stance, the gestures are direct, intentional and illustrate or enhance the message and the arm movements are controlled but also wide-reaching, to expand the visual personal space. Fingers are held up around an imaginary box or ball to give away the energy, not flopping down from the wrist to diminish energy. The use of "verbal bullets" has the effect of increasing the credibility of the speaker when points are counted out on each finger in front of the body to clarify each point being made verbally.

\section{Vocal impact}

Albert Mehrabian's studies on communication determined that tone of voice contributed to $38 \%$ of the communication, body language $55 \%$ and words a mere $7 \%$. In our experiments we have found that words are not remembered either so that $7 \%$ is reduced to maybe a phrase or two. As actors have always known, a change of tone can alter the intended meaning of our words and is a vital ingredient in how the communication is received. It is therefore an extremely important aspect of our total image. Small adjustments can be made by image consultants but if we do not have the benefit of acting techniques we can enlist the aid of voice specialists to help us with a client's tone, pitch, accent modification, projection, clarity and articulation to alter the quality of the voice.

For example, a monotone voice is hard to concentrate on, and people stop listening. Wellmodulated and varied phrasing, emphasis and speed are techniques to be learned to ensure that the speaker sounds confident and entertaining. Warmth is conveyed by a soft toned but clear register voice, a voice range that is medium to low register with appropriate tonality resonates more than a high register. High registers can be strident and grating on the ears and denote a young or inexperienced person's voice. We also speak higher or lower when we are scared, angry or lack confidence as the throat muscles contract with emotion and the voice is thin and constrained. Power and credibility are demonstrated by a medium voice register that projects from low in the abdomen to the back of the room and a very fluent flow of words without fillers or gaps. British Prime Minister Maggie Thatcher had to learn those skills as her high pitched upper class accent was mocked by constituents and she was in danger of losing both credibility and warmth

\section{Synopsis}

- Practicing techniques to alter the mood and perception of their audience.

- Learning to talk to people, not talk $\boldsymbol{a t}$ them. They avoid lecturing, giving unsolicited advice or trying to fix their faults.

- Speaking to the needs and values of the audience.

- Adopting an "Ask, don't tell" style, so it becomes easier to discover what is important to the other.

- Using positive language which is future based and includes acknowledgements of people's contribution, goals and outcomes.

- Purging negative language, avoiding what is wrong, blame, justifications and excuses. 
- Knowing how to express their values and vision without "preaching".

- Getting to know people and avoid conflict. This promotes trust and avoids judgement, thus creating closer professional relationships.

\section{Integrity, walk the talk. The overarching skill in executive presence}

Our students and Executive Presence clients are coached in this skill. Integrity actually means complete and whole like a circle; people with integrity have no gaps in their performance, they are known for being sound and trustworthy. They keep their word rather than dishing out excuses or justifications; they deliver the results. Integrity can be as simple as being on time to as complex as meeting key sales measures or producing a successful event. It is an important quality for an executive because their clients and associates are only interested in how they put things right if things go wrong. Just as multinational brands recall any faulty product as soon as it's discovered, a person with integrity remedies the situation however much they lose face. We explain that nobody can be complacent here as there is always work to do to restore our integrity. When we are operating in Executive Presence mode we can always rectify our crass behavior, our miscommunications and our thoughtless actions. As a person with executive presence we must think of ourselves as if we were a ship at sea, constantly "Correcting to True North".

\section{Goal setting}

How often have we felt a failure when we fell short of a goal? We justified, made excuses, procrastinated or gave up entirely. Confidence is enhanced by small or simple wins and accomplishments: when our to-do list is fully crossed off within our deadline, when we push through our fears to master a skill like public speaking and when we fell short of a losing the weight yet stayed on the plan regardless, we start to trust our judgements and gain a renewed sense of personal power and purpose. Rather than time management, goal setting should be renamed as self-management in time. Managing yourself in time requires an awareness of the tapes in the head influencing your thoughts and actions. Rather than saying "I must have self-discipline" which is a concept and soon forgotten, it's imperative that we manage our actions and circumstances with fallback strategies and action plans. It's also enormously useful to be accountable for our actions and report to a coach or to an assigned "boss".

As we know full well from our new year's resolutions, we are weak in the area of goal setting and fulfillment. To be a true goal the situation always has a time element, and a specific result or outcome. "I'm going to lose some weight by the end of the year" is not a goal. "I will lose $10 \mathrm{kgs}$ by December 31," is a goal.

One of my younger clients took on a project to design and implement a big external event for her non-profit company. She had never even attempted such a large undertaking, and was most comfortable staying in the background, in a support role. In this case she had recently lost a coworker and had to come through herself with the result. As she retold the 
story, the language in her account changed to become clear and articulate. She said that she was forced to fulfill written goals every week and could never procrastinate; she found her voice and made requests of people she had considered intimidating. She organized countless details and even worked extra hours when necessary. Looking back, she saw that she was amazingly effective. Could she transfer those skills to other situations? At the time, we worked with her on the next project. At first she hung back and forgot how well she could operate at peak performance. Ultimately we said that she faced a choice: would she prefer to entertain herself with the useless mindset and tapes that played in the background making her feel a failure? Or would she prefer to lead a life she was proud of? She found that she liked being productive and successful, so she chose to put her back into work projects.

Another of our clients wanted to become more effective in his role as manager in the technical support department and he became one of our Executive Presence clients. He was a promising young manager but reported that his older team never did anything he said. In the process to define and access his values the DiSC survey and 360' Reach tool was employed to distinguish weak skills and areas he needed to work on. Once his accomplishments and areas of improvement were made transparent his overt anxiety dissipated somewhat. With our support, he was able to identify goals and go to work on improving his collegiate appearance and unprofessional communication, first personally and then with his team. In his case and that of other clients, identifying weaknesses isn't pleasant but it can promote honest action which has the remarkable ability to separate the emotions from the future goals to be fulfilled. In other words, working out at the gym is more rewarding than thinking about going to the gym or worse, thinking about planning to go to the gym. In the case of our young client, he said that he gained insight into the ingredients of self-confidence. He saw it now as a function of intentional action, rather than a psychological state of mind which he was not capable of achieving.

\section{Maintaining confidence in the face of adversity}

This is an important element for our Executive Presence clients to master. Things don't always go smoothly! Adverse situations are the building blocks of self -trust, self- confidence and the enhancement of self-esteem. When things go wrong we tend to listen to the negative thoughts. I love the acronym of Fear: False Evidence Appearing Real. Confidence is an elusive mindset that waxes and wanes depending on how much we blame ourselves, others or circumstances. The inventor Thomas Edison had countless appalling circumstances to overcome including the burning to the ground of his entire four building empire where he housed his inventions. He just laughed and rebuilt it.

\section{Synopsis}

- Learning specific language to move, touch and inspire people to action.

- Learning intentional action and what to do when things go wrong.

- How to get back on track in goal setting with fallback strategies. 
- Putting in place structures such as support from external sources.

- Chunking the project into priorities and interim, smaller goals.

- Separating emotion from goal setting.

- Keeping a cool head, admit any missteps committed.

- Learn from their mistakes and rectify them next time.

- View critiquing, far from being a personal attack on their character is viewed as a contribution to their growth.

- View adverse circumstances as powerful learning experiences.

This is done at the end of every section and at the end of the program. After working with clients for over thirty years, I have found that our clients and students gain self-confidence that is measurable, assessable and observable.

\section{Biography References}

Wenner, M. (2009). Scientific America. Aviable at https://www.scientificamerican.com/ article/the-serious-need-for-play/?redirect $=1$

Mehrabian, A. (1996). Pleasure-arousal-dominance: A general framework for describing and measuring individual differences in Temperament.. Springer Science+Business Media New York 2014

Resumen: El propósito y objetivo de este resumen es demostrar que los servicios de consultoría de imagen ayudan a aumentar la confianza en sí mismos de los clientes. Nuestros clientes en el London Image Institute son empresarios y ejecutivos. Después de años de perfeccionar nuestros programas y cursos de Presencia Ejecutiva para empresarios, notamos que estas técnicas, habilidades y programas de capacitación son particularmente efectivos para mejorar la confianza en sí mismos, incluso en empresarios y empresarios de alto nivel. Compartiremos las agendas de los programas con los lectores, así como algunos de los métodos mediante los cuales cambiamos la mentalidad y generamos conjuntos de habilidades sostenibles que cambian vidas. Al final de cada sección habrá una breve sinopsis de las prácticas de consultoría de imagen que nuestros clientes informaron que fueron más efectivas en la creación de confianza.

Palabras clave: Ejecutivo - presencia - confianza en sí mismo - confianza en sí mismo autoestima - autoestima - autogestión - asesoría de imagen.

Resumo: O objetivo e objetivo deste resumo é demonstrar que os serviços de consultoria de imagem ajudam a aumentar a autoconfiança dos clientes. Nossos clientes no London Image Institute são empresários e executivos. Ao longo de anos, aperfeiçoando nossos programas e cursos de Presença Executiva para empreendedores, percebemos que essas 
técnicas, habilidades e programas de coaching são particularmente eficazes para aumentar a autoconfiança, mesmo em empresários e empreendedores de alto nível. Vamos compartilhar as agendas dos programas com os leitores, bem como alguns dos métodos pelos quais mudamos a mentalidade e criamos conjuntos de habilidades de mudança de vida sustentada. No final de cada seção, haverá uma pequena sinopse das práticas de consultoria de imagem que nossos clientes relataram serem mais eficazes na criação de confiança.

Palavras chave: Executivo - presença - autoconfiança - autoconfiança - autoestima - autoestima - autogestão - consultoria em imagem.

[Las traducciones de los abstracts fueron supervisadas por el autor de cada artículo] 